Pak. J. Agri. Sci., Vol. 54(2), 277-286; 2017

ISSN (Print) 0552-9034, ISSN (Online) 2076-0906

DOI: 10.21162/PAKJAS/17.4486

http://www.pakjas.com.pk

\title{
THE IMPACT OF TREATMENT OF ORGANIC MANURES ON FUTURE SOIL CARBON SEQUESTRATION UNDER DIFFERENT TILLAGE SYSTEMS IN PAKISTAN
}

\author{
Khuram Shahzad ${ }^{1,2, *}$, Ayub Khan ${ }^{1}$, Mark Richards² and Jo U. Smith ${ }^{2}$ \\ ${ }^{1}$ Department of Agricultural Sciences, University of Haripur-22060, Pakistan; ${ }^{2}$ Institute of Biological and \\ Environmental Sciences, School of Biological Sciences, University of Aberdeen, 23 St. Machar Drive, Aberdeen, \\ AB24 3UU, Scotland, UK. \\ "Corresponding author's e-mail address: ks_uaf@yahoo.com
}

\begin{abstract}
Field experiments were conducted at Gujjar Seed and Nursery Farm, Haripur, Pakistan to investigate impact of incorporating differently treated of organic manures using different tillage systems on soil carbon. Maximum increase in soil carbon was observed when the required nitrogen was applied as bioslurry produced from cattle manure by anaerobic digestion. This was significantly greater than when the required amount of nitrogen was applied as composted poultry manure or chemical fertilizer. Minimum tillage also resulted in a significant increase of soil carbon compared to conventional or deep tillage These experimental measurements were used to evaluate a dynamic simulation model of soil organic matter turnover, RothC which was then used to estimate future carbon sequestration. The correlation between experimental and simulated values was highly significant and the root mean square error was within experimental error, suggesting that RothC is providing an acceptable representation of the changes in soil carbon that is occurring in this experiment. The uncertainty in simulations was less than 3\%. Simulations were done using future weather scenarios; these suggest that addition of the recommended rate of nitrogen in $8.4 \mathrm{t} \mathrm{ha}^{-1} \mathrm{y}^{-1}$ bioslurry every year increases soil carbon sequestration over 100 years (2012-2112) by $24.9 \pm 0.74 \mathrm{t} \mathrm{ha}^{-1}$ compared to the control where no organic manure was applied. This sequesters $7.5 \pm 0.24 \mathrm{tha}^{-1}$ more carbon than if the same amount of nitrogen is applied as poultry manure, requiring an application rate of $7.5 \mathrm{tha}^{-1} \mathrm{y}^{-1}$. If the same amounts of bioslurry and poultry manure are applied, carbon sequestration is still significantly greater for bioslurry than for poultry manure $\left(4.5 \pm 0.2 \mathrm{t} \mathrm{ha}^{-1}\right)$. Losses of carbon with climate change were highest under climate scenario B2 (environmental protection with regionalization) and B1 (environmental protection with globalization), followed by A1B (economic growth with globalization), with minimum losses from A2 (economic growth with regionalization). These predicted losses are likely to be more than compensated for by application of organic fertilizers at the rates needed to supply sufficient nitrogen to the crops.
\end{abstract}

Keywords: Soil carbon sequestration, organic manures, bioslurry, poultry manure, nitrogen sources, RothC.

\section{INTRODUCTION}

Soil organic matter (SOM) is important for mitigating the impacts of climate change and for sustaining the soil productivity (Khan et al., 2006. It provides a reservoir of nutrients, especially nitrogen $(\mathrm{N})$, phosphorus $(\mathrm{P})$, potassium $(\mathrm{K})$, sulphur (S) and micronutrients, and can reduce leaching losses. The average organic matter content of soils in Pakistan is less than $10 \mathrm{~g} \mathrm{~kg}^{-1}$ (Khalid et al., 2012), while productive soils usually require SOM levels of $25-30 \mathrm{~g} \mathrm{~kg}^{-1}$ (Islam, 2006). The organic matter content of these soils is reducing due to low organic inputs and a climate that is conducive to decomposition. Deep tillage increases soil aeration and further accelerates decomposition of SOM (Post and Kwon, 2000). Reduced tillage and addition of organic residues are suggested to be cost-effective and environmentally friendly methods of enhancing soil carbon (C) sequestration (Victoria et al., 2012).
Soils hold a large proportion of the global C, so can have a significant impact on atmospheric C; Smith et al. (2008) estimated a global total of $1500 \mathrm{Pg} \mathrm{C}$ stored in soil as compared to $760 \mathrm{Pg} \mathrm{C}$ in the atmosphere. Approximately 30$50 \%$ of soil organic C (SOC) is lost due to intensive tillage practices (Davidson and Ackerman, 1993). Lal (2002) asserts that improved SOC management is the best option for mitigating global climate change in the short term. The estimated potential of SOC sequestration in Pakistan is 8-15 Tg per year with a monetary value of $\$ 800-1000$ million per year @ European union price of $\$ 20 \mathrm{Mg}^{-1} \mathrm{CO}_{2}$ (Khan and Lal, 2007).

Fertilizer applications can affect SOM content, but reports of impacts are contradictory. Some studies suggest that inorganic $\mathrm{N}$ fertilizer increases SOC over unfertilized plots (Batlle-Bayer et al., 2010), whereas others show that SOC either does not change (López-Bellido et al. 2010) or decreases with fertilizer application ( $\mathrm{Li}$ and Zhang, 2007). 
Bioslurry, the residue from anaerobic digestion, can be used as a high quality organic fertilizer. During the digestion process in a biogas plant in Bangladesh, only $25-30 \%$ of the organic matter was converted into biogas, leaving $70-75 \%$ in the bioslurry (Islam, 2006; Bashir et al., 2016). In Cambisols of Southern Brazil, Mellek et al. (2010) observed that bioslurry from dairy cattle manure improved soil structure, increased porosity and water infiltration rate, and reduced soil bulk density. If it is properly stored, handled and spread, poultry manure can also provide an inexpensive source of plant nutrients and is widely available in Pakistan due to rapid growth of the poultry industry. Kingery et al. (1994) observed that application of poultry manure can increase SOM content to improve soil quality and productivity.

The objective of this study is to investigate the potential of bioslurry and poultry manure to improve SOC sequestration when combined in different proportions with fertilizer, and to investigate long term impacts under the changing weather conditions of Haripur-Hazara Division of Pakistan. The null hypotheses to be tested are

1. Application of the crop requirement of nitrogen as dairy cattle bioslurry does not increase the carbon content of the soil over application as chemical fertilizer.

2. Application of the crop requirement of nitrogen as composted poultry manure does not increase the carbon content of the soil over application as chemical fertilizer.

3. Application of the crop requirement of nitrogen as dairy cattle bioslurry does not increase the carbon content of the soil over application as composted poultry manure.

4. Depth of tillage does not impact the amount of carbon in the soil.

\section{MATERIALS AND METHODS}

The site: The two year field study (2012-13) was conducted at Gujjar and Seed Nursery Farm, Mung, Haripur, Pakistan (LAT. $33.90{ }^{\circ} \mathrm{N}$, LONG. $72.91{ }^{\circ} \mathrm{E}$ and ALT. $565 \mathrm{~m}$ ). The climate is humid subtropical (Koppen Climate Classification), categorized by high temperatures and evenly distributed rainfall throughout the year. The soil of experimental site belongs to Udic Calciustepts (Sub group) according to USDA soil classification. The soil from 0-30 $\mathrm{cm}$ is a silt loam $(21.2 \%$ sand, $60.0 \%$ silt and $18.8 \%$ clay by volume), with $\mathrm{pH} 7.8, \mathrm{CaCO}_{3}$ content $8.75 \%$ by volume, total soluble salts $0.016 \mathrm{mg} \mathrm{dm}^{-3}$, organic matter content 4.9 $\mathrm{g} \mathrm{kg}^{-1}$, total $\mathrm{N} 0.24 \mathrm{~g} \mathrm{~kg}^{-1}$, available $\mathrm{P} 1.35 \mathrm{mg} \mathrm{kg}^{-1}$, available $\mathrm{K} 53 \mathrm{mg} \mathrm{kg}^{-1}$ and bulk density $1.45 \mathrm{~g} \mathrm{~cm}^{-3}$.

Experimental layout: The experiments used a randomized complete block design with a split plot arrangement; the tillage systems in the main plots and $\mathrm{N}$ treatments in subplots. Each treatment was replicated four times. Net sub-plot size of each sub-plot was $4.5 \mathrm{~m} \mathrm{x} 4.5 \mathrm{~m}$. The maize crop (Zea mays cv. Azam) was sown on $8^{\text {th }}$ July 2012, with a second crop on $7^{\text {th }}$ July 2013. In all plots except the control, the recommended levels of $\mathrm{P}$ and $\mathrm{K}$ (125 and $125 \mathrm{~kg} \mathrm{ha}^{-1}$ ) were applied as chemical fertilizer; this was to ensure that available $\mathrm{P}$ and $\mathrm{K}$ did not limit crop growth or decomposition in these trials and we were only investigating the impact of $\mathrm{C}$ and $\mathrm{N}$. In the control, no chemical or organic fertilizers were applied. The amount of poultry manure or bioslurry to be applied was calculated from the chemical analysis of total $\mathrm{N}$. The $\mathrm{N}$ in chemical fertilizer was added as urea and di-ammonium phosphate, $\mathrm{P}$ as di-ammonium phosphate and $\mathrm{K}$ as potassium sulphate. The recommended dose of $\mathrm{P}$ and $\mathrm{K}$ in chemical fertilizer was incorporated at the time of sowing, and $\mathrm{N}$ was applied in two splits (at sowing and at flowering). Irrigation was applied equally across all treatments at two weekly intervals, in addition to the rainfall received during the growing period of the crop, up until the physiological maturity of the crop. Thinning was done at 3 to 4 leaf stage to keep a single plant at each position. The crop was kept free from weeds by manual hoeing. Other agronomic managements, such as insecticide application, was kept even for all treatments. The crop was harvested manually on $4^{\text {th }}$ November 2012 and $9^{\text {th }}$ November 2013.

Applications of organic fertilizer: The $35 \mathrm{~m}^{3}$ biogas plant, located at Muhammad Sidique Farm Haripur, Pakistan, constructed during 2010, was initialized using $27.9 \mathrm{~m}^{3}$ cattlederived farmyard manure. Daily input of $200 \mathrm{~kg}$ cattle farmyard manure produced $9 \mathrm{~kg} \mathrm{day}^{-1} \mathrm{CH}_{4}$ and $200 \mathrm{~kg} \mathrm{day}^{-1}$ bioslurry. Two-week-old bioslurry was collected from the outlet of the biogas plant, sun dried, ground, and then applied to respective treatment plots three weeks before sowing maize (2012-13), mixing to a depth of $20 \mathrm{~cm}$ using a disc plough to avoid $\mathrm{N}$ losses from surface application. Poultry manure (poultry excreta with bedding material) was collected from an environmentally controlled poultry shed on the same farm containing $8000-16000$ broiler birds. The temperature in the shed was $24^{\circ} \mathrm{C}$ and relative humidity was $60-70 \%$. The poultry manure was allowed to decompose naturally in pits in the shade for three months before application, three weeks before sowing maize (2012-13), to respective treatment plots by mixing to a depth of $20 \mathrm{~cm}$ using a disc plough. Samples of bioslurry and poultry manure were analysed for organic $\mathrm{C}$ and organic matter contents by the method described by Brake (1992), total $\mathrm{N}$ by Kjeldahl digestion (Van Schouwenberg and Walinge, 1973), and $\mathrm{P}$ and $\mathrm{K}$ were determined after wet digestion (Ryan et al., 2001), for P by spectrophotometer (Watanabe and Olsen, 1965) and for $\mathrm{K}$ by flame analyzer (Winkleman et al., 1986). Bioslurry contained $16 \mathrm{~g} \mathrm{~kg}^{-1} \mathrm{~N}, 15.7 \mathrm{~g} \mathrm{~kg}^{-1} \mathrm{P}$, $13.5 \mathrm{~g} \mathrm{~kg}^{-1} \mathrm{~K}, 336 \mathrm{~g} \mathrm{~kg}^{-1} \mathrm{C}$ and $580 \mathrm{~g} \mathrm{~kg}^{-1}$ organic matter, while poultry manure contained $18 \mathrm{~g} \mathrm{~kg}^{-1} \mathrm{~N}, 14.2 \mathrm{~g} \mathrm{~kg}^{-1} \mathrm{P}$, $12.6 \mathrm{~g} \mathrm{~kg}^{-1} \mathrm{~K}, 354 \mathrm{~g} \mathrm{~kg}^{-1} \mathrm{C}$ and $610 \mathrm{~g} \mathrm{~kg}^{-1}$ organic matter. 
Table 1. Fertilizer treatments used in the trials.

\begin{tabular}{|c|c|c|c|c|c|c|c|c|c|c|c|c|c|c|c|c|}
\hline \multicolumn{4}{|c|}{$\begin{array}{l}\text { Percentage of recommended } \mathrm{N} \\
\text { application rate }\end{array}$} & \multicolumn{5}{|c|}{ Poultry Manure } & \multicolumn{5}{|c|}{ Bioslurry } & \multicolumn{3}{|c|}{ Chemical Fertilizer } \\
\hline & $\begin{array}{l}\text { Poultry } \\
\text { manure }\end{array}$ & Bioslurry & $\begin{array}{l}\text { Chemical } \\
\text { fertilizer }\end{array}$ & $\begin{array}{c}\text { Fresh } \\
\text { weight }(\mathrm{t} \\
\left.\mathrm{ha}^{-1}\right)\end{array}$ & $\begin{array}{c}\mathrm{C} \\
\left(\mathrm{kg} \mathrm{ha}^{-1}\right)\end{array}$ & $\begin{array}{c}\mathrm{N} \\
\left(\mathrm{kg} \mathrm{ha}^{-1)}\right.\end{array}$ & $\begin{array}{c}\mathrm{P} \\
\left(\mathrm{kg} \mathrm{ha}^{-1}\right)\end{array}$ & $\begin{array}{c}\mathrm{K} \\
\left(\mathrm{kg} \mathrm{h}^{-1}\right)\end{array}$ & $\begin{array}{l}\text { Fresh } \\
\text { weight } \\
\left(\mathrm{t} \mathrm{ha}^{-1}\right)\end{array}$ & $\begin{array}{c}\mathrm{C} \\
\left(\mathrm{kg} \mathrm{ha}^{-1}\right)\end{array}$ & $\begin{array}{c}\mathrm{N} \\
\left(\mathrm{kg} \mathrm{ha}^{-1}\right)\end{array}$ & $\begin{array}{c}\mathrm{P} \\
\left(\mathrm{kg} \mathrm{ha}^{-1}\right)\end{array}$ & $\begin{array}{c}\mathrm{K} \\
\left(\mathrm{kg} \mathrm{ha}^{-1}\right)\end{array}$ & $\begin{array}{c}\mathrm{N} \\
\left(\mathrm{kg} \mathrm{ha}^{-1}\right)\end{array}$ & $\begin{array}{c}\mathrm{P} \\
\left(\mathrm{kg} \mathrm{ha}^{-1}\right)\end{array}$ & $\begin{array}{c}\mathrm{K} \\
\left(\mathrm{kg} \mathrm{ha}^{-1}\right)\end{array}$ \\
\hline $\mathrm{N}_{1}$ & 0 & 0 & 0 & - & - & - & - & - & - & - & - & - & - & - & - & - \\
\hline $\mathrm{N}_{2}$ & 0 & 0 & 100 & - & - & - & - & - & - & - & - & - & - & 135 & 125 & 125 \\
\hline $\mathrm{N}_{3}$ & 100 & 0 & 0 & 7.5 & 2670 & 135 & 107 & 95 & - & - & - & - & - & - & 125 & 125 \\
\hline $\mathrm{N}_{4}$ & 0 & 100 & 0 & - & - & - & - & - & 8.4 & 2832 & 135 & 132 & 114 & - & 125 & 125 \\
\hline $\mathrm{N}_{5}$ & 50 & 0 & 50 & 3.8 & 1335 & 67.5 & 54 & 48 & - & - & - & - & - & 67.5 & 125 & 125 \\
\hline $\mathrm{N}_{6}$ & 0 & 50 & 50 & - & - & - & - & - & 4.2 & 1416 & 67.5 & 66 & 57 & 67.5 & 125 & 125 \\
\hline $\mathrm{N}_{7}$ & 50 & 50 & 0 & 3.8 & 1335 & 67.5 & 54 & 48 & 4.2 & 1416 & 67.5 & 66 & 57 & - & 125 & 125 \\
\hline $\mathrm{N}_{8}$ & 25 & 25 & 50 & 1.9 & 668 & 33.8 & 27 & 24 & 2.1 & 708 & 33.8 & 33 & 28 & 67.5 & 125 & 125 \\
\hline $\mathrm{N}_{9}$ & 50 & 25 & 25 & 3.8 & 1335 & 67.5 & 54 & 48 & 2.1 & 708 & 33.8 & 33 & 28 & 33.8 & 125 & 125 \\
\hline $\mathrm{N}_{10}$ & 25 & 50 & 25 & 1.9 & 668 & 33.8 & 27 & 24 & 4.2 & 1416 & 67.5 & 66 & 57 & 33.8 & 125 & 125 \\
\hline
\end{tabular}

Note $-\mathrm{P}$ and $\mathrm{K}$ added as chemical fertilizer to ensure $\mathrm{P}$ and $\mathrm{K}$ did not limit crop growth.

The ten treatments used a combination of organic and inorganic fertilizers to add $\mathrm{N}, \mathrm{P}$ and $\mathrm{K}$ at the recommended rates of 135,125 and $125 \mathrm{~kg} \mathrm{ha}^{-1}$. The $\mathrm{N}$ treatments used and the amounts of $\mathrm{C}, \mathrm{N}, \mathrm{P}$ and $\mathrm{K}$ added in each treatment are given in Table 1.

Tillage: Minimum, conventional and deep tillage was used with the ten different $\mathrm{N}$ treatments. Minimum tillage was carried out using a rotavator to $4-6 \mathrm{~cm}$, conventional tillage by tine plough to $30 \mathrm{~cm}$ and deep tillage by chisel plough to $45 \mathrm{~cm}$.

Measurement of change in soil carbon: After harvest of the crop, soil samples were taken from 0-30 cm. Samples were air dried in the shade, ground and passed through a $2 \mathrm{~mm}$ sieve. These samples were stored and analyzed for SOC by the modified Walkley-Black method (Walkley and Black, 1934). Total SOC was determined as described by Smith (2000) as where, TOC is total SOC stock $\left(\mathrm{t} \mathrm{ha}^{-1}\right), C$ is measured $\mathrm{C}(\%)$, $\rho b$ is soil bulk density $\left(\mathrm{g} \mathrm{cm}^{-3}\right)$ and $D$ is soil depth $(\mathrm{cm})$. If there has been a significant change in bulk density, it is necessary to adjust the depth of soil included in the calculation of soil $\mathrm{C}$ to include an equivalent soil mass (Ellert and Bettany, 1995). However, in practice, the change in bulk density was not sufficient to significantly change the depth of soil included in this calculation, so a constant depth of $30 \mathrm{~cm}$ was used. The change in $\mathrm{C}$ in SOC, $\triangle \mathrm{TOC}\left(\mathrm{t} \mathrm{ha}^{-1} \mathrm{y}^{-}\right.$ $\left.{ }^{1}\right)$, was then calculated as (2)where, TOC treatment and $\mathrm{TOC}_{\text {control }}$ are $\mathrm{SOC}$ in treatment and control respectively $(\mathrm{t}$ $\mathrm{ha}^{-1}$ ), and $\mathrm{t}$ is the length of the experiment (y).

Statistical analysis of experimental data: The data collected in each year were analyzed using Statistix 8.1 software (Analytical Software, Statistix; Tallahassee, FL, USA, 19852003). Each data point was the mean of four replicates $(n=$ 4). The Tukey's Honestly Significant Difference (HSD) test at $5 \%$ probability was used to compare differences among

Table 2. Soil characteristics used in RothC simulations.

\begin{tabular}{|c|c|c|c|c|c|c|c|c|c|c|c|c|c|}
\hline & \multicolumn{3}{|c|}{$\begin{array}{l}{ }^{1} \text { At start of experiment } \\
\text { (assumed steady state) }\end{array}$} & \multicolumn{5}{|c|}{${ }^{1}$ At harvest 2012} & \multicolumn{5}{|c|}{${ }^{1}$ At harvest 2013} \\
\hline & $\begin{array}{c}\text { Bulk } \\
\text { density } \\
\left(\mathrm{g} \mathrm{cm}^{-3}\right)\end{array}$ & $\begin{array}{l}\text { Depth } \\
(\mathrm{cm})\end{array}$ & $\begin{array}{l}\mathrm{SOC} \\
\left(\mathrm{t} \mathrm{ha}^{-1}\right)\end{array}$ & $\begin{array}{c}\text { Bulk } \\
\text { density } \\
\left(\mathrm{g} \mathrm{cm}^{-3}\right)\end{array}$ & $\begin{array}{l}\text { Depth } \\
(\mathrm{cm})\end{array}$ & $\begin{array}{c}\mathrm{SOC} \\
\left(\mathrm{t} \mathrm{ha}^{-1}\right)\end{array}$ & $\begin{array}{c}{ }^{2} \text { Biological } \\
\text { yield } \\
\left(\mathrm{t} \mathrm{ha}^{-1}\right)\end{array}$ & $\begin{array}{c}{ }^{2} \text { Harve } \\
\text { st } \\
\text { index }\end{array}$ & $\begin{array}{c}\text { Bulk } \\
\text { density } \\
\left(\mathrm{g} \mathrm{cm}^{-3}\right)\end{array}$ & $\begin{array}{c}\text { Depth } \\
(\mathrm{cm})\end{array}$ & $\begin{array}{c}\mathrm{SOC} \\
\left(\mathrm{t} \mathrm{ha}^{-1}\right)\end{array}$ & $\begin{array}{c}{ }^{2} \text { Biologic } \\
\text { al yield } \\
\left.(\mathrm{t} \mathrm{ha})^{-1}\right)\end{array}$ & $\begin{array}{c}{ }^{2} \text { Harvest } \\
\text { index }\end{array}$ \\
\hline$\overline{\mathrm{N}_{1}}$ & 1.45 & 30 & 12.18 & $1.43^{\mathrm{a}}$ & 30 & $12.29^{\mathrm{d}}$ & $9.7^{\mathrm{h}}$ & $22.1^{\mathrm{bc}}$ & $1.42^{\mathrm{a}}$ & 30 & $12.69^{\mathrm{e}}$ & $9.7^{\mathrm{g}}$ & $24.2^{b}$ \\
\hline $\mathrm{N}_{2}$ & 1.45 & 30 & 12.18 & $1.42^{\mathrm{ab}}$ & 30 & $12.36^{\mathrm{d}}$ & $16.4^{\mathrm{ab}}$ & $26.1^{\mathrm{a}}$ & $1.41^{\mathrm{ab}}$ & 30 & $12.82^{\mathrm{e}}$ & $16.4^{\mathrm{a}}$ & $27.2^{\mathrm{a}}$ \\
\hline $\mathrm{N}_{3}$ & 1.45 & 30 & 12.18 & $1.34^{\mathrm{ef}}$ & 30 & $13.41^{\mathrm{ab}}$ & $14.7^{\mathrm{d}}$ & $21.9^{\mathrm{bc}}$ & $1.33^{\mathrm{d}-\mathrm{f}}$ & 30 & $13.69^{\mathrm{ab}}$ & $14.8^{\mathrm{c}}$ & $22.6^{\mathrm{bc}}$ \\
\hline $\mathrm{N}_{4}$ & 1.45 & 30 & 12.18 & $1.32^{\mathrm{f}}$ & 30 & $13.52^{\mathrm{a}}$ & $11.6^{\mathrm{g}}$ & $22.1^{\mathrm{bc}}$ & $1.31^{\mathrm{g}}$ & 30 & $13.82^{\mathrm{a}}$ & $11.8^{\mathrm{f}}$ & $22.9^{\mathrm{bc}}$ \\
\hline $\mathrm{N}_{5}$ & 1.45 & 30 & 12.18 & $1.40^{\mathrm{a}-\mathrm{c}}$ & 30 & $12.54^{\mathrm{cd}}$ & $15.8^{\mathrm{a}-\mathrm{c}}$ & $23.1^{\mathrm{b}}$ & $1.38^{\mathrm{b}-\mathrm{d}}$ & 30 & $13.29^{\mathrm{cd}}$ & $15.9^{\mathrm{ab}}$ & $23.6^{\mathrm{bc}}$ \\
\hline $\mathrm{N}_{6}$ & 1.45 & 30 & 12.18 & $1.39^{b-d}$ & 30 & $12.45^{\mathrm{d}}$ & $15.6^{\mathrm{bc}}$ & $20.9^{c}$ & $1.35^{\mathrm{d}-\mathrm{f}}$ & 30 & $13.34^{\mathrm{c}}$ & $15.7^{\mathrm{ab}}$ & $21.9^{b c}$ \\
\hline $\mathrm{N}_{7}$ & 1.45 & 30 & 12.18 & $1.33^{\mathrm{f}}$ & 30 & $12.72^{\mathrm{c}}$ & $13.4^{\mathrm{e}}$ & $21.3^{\mathrm{bc}}$ & $1.32^{\mathrm{fg}}$ & 30 & $13.11^{\mathrm{d}}$ & $13.6^{\mathrm{d}}$ & $22.0^{\mathrm{bc}}$ \\
\hline $\mathrm{N}_{8}$ & 1.45 & 30 & 12.18 & $1.41^{\mathrm{a}-\mathrm{c}}$ & 30 & $12.75^{\mathrm{c}}$ & $16.4^{\mathrm{a}}$ & $26.7^{\mathrm{a}}$ & $1.39^{\mathrm{a}-\mathrm{c}}$ & 30 & $13.58^{b}$ & $16.4^{\mathrm{a}}$ & $27.8^{\mathrm{a}}$ \\
\hline $\mathrm{N}_{9}$ & 1.45 & 30 & 12.18 & $1.38^{\mathrm{c}-\mathrm{e}}$ & 30 & $13.34^{\mathrm{ab}}$ & $15.1^{\mathrm{cd}}$ & $21.3^{\mathrm{bc}}$ & $1.36^{\mathrm{c}-\mathrm{e}}$ & 30 & $13.61^{\mathrm{ab}}$ & $15.2^{\mathrm{bc}}$ & $22.1^{\mathrm{bc}}$ \\
\hline $\mathrm{N}_{10}$ & 1.45 & 30 & 12.18 & $1.35^{\mathrm{d}-\mathrm{f}}$ & 30 & $13.25^{\mathrm{b}}$ & $12.6^{\mathrm{f}}$ & $21.4^{\mathrm{bc}}$ & $1.33^{\mathrm{e}-\mathrm{g}}$ & 30 & $13.57^{\mathrm{b}}$ & $12.8^{\mathrm{e}}$ & $21.7^{\mathrm{c}}$ \\
\hline HSD5\% & - & - & - & 0.0392 & - & 0.246 & 0.73 & 2.16 & 0.035 & - & 0.226 & 0.767 & 2.567 \\
\hline
\end{tabular}

Note: Soil bulk density, SOC were measured at $0-30 \mathrm{~cm}$ soil depth. ${ }^{1}$ values assumed to remain constant for the duration of the experiment are clay content $=18.8 \%$, water content at wilting point $=30 \mathrm{~mm}$ in $30 \mathrm{~cm}$ depth of soil, water content at field $=90 \mathrm{~mm}$ in $30 \mathrm{~cm}$ depth of soil; ${ }^{2}$ values from Shahzad et al. (2015). The values derived from 12 observations. 
treatment means (Steel and Torrie, 1984).

Simulation of the carbon content measured in trials: The RothC-26.3 model of $\mathrm{C}$ turnover in soils (Coleman and Jenkinson, 1996) was used to simulate changes in soil C content following application of urea, bioslurry and poultry manure. Because the differences in soil $\mathrm{C}$ stocks with $\mathrm{N}$ treatments in the different tillage systems was not statistically significant, the impact of tillage was not explicitly simulated; the simulations used the mean measurements in each $\mathrm{N}$ treatment over all tillage systems. Simulating the impact of applications of bioslurry compared to poultry manure in the field is a new application of RothC; previously, this has only been done using laboratory data (Smith et al., 2014). Changes in plant inputs were accounted for in proportion to changes in yield. Decomposability of incorporated organic manure was defined using the proportion of decomposable plant material (DPM) to stabilized organic matter (HUM), following the approach presented by Smith et al. (2014). The decomposition rate constants of these pools are defined as $10 \mathrm{y}^{-1}$ for DPM and $0.02 \mathrm{y}^{-1}$ for HUM (Coleman and Jenkinson, 1996), so the ratio of DPM to HUM determines the rate of organic manure decomposition. Incubation studies by Bernal et al. (1998) and Marcato et al. (2009) provided data to set the ratio of DPM:HUM in poultry manure and bioslurry. According to Smith et al. (2014), this gave a DPM:HUM ratio of 31.45 for poultry manure and 0.14 for bioslurry. Monthly inputs of poultry manure or bioslurry were applied according to the management of the trial, initially using the DPM:HUM ratios given by Smith et al. (2014).

Inputs required by the model are crop yield, air temperature $\left({ }^{\circ} \mathrm{C}\right)$, monthly rainfall $(\mathrm{mm})$, monthly open-pan evaporation $(\mathrm{mm})$, soil texture (\% clay content), $\mathrm{pH}$, average soil water content $(\mathrm{mm})$, SOC content $\left(\mathrm{t} \mathrm{ha} \mathrm{ha}^{-1}\right)$, land use and management data (Table 2). Plant inputs needed to achieve the measured soil $\mathrm{C}$ before the trials started were estimated by running the model to steady state using default plant inputs, and then adjusting plant inputs according to the ratio of measured and simulated SOC contents (Smith et al., 2005); (3) where is plant $\mathrm{C}$ input used in the next iteration $\left(\mathrm{t} \mathrm{ha} \mathrm{a}^{-1}\right)$, is measured soil $\mathrm{C}\left(\mathrm{t} \mathrm{ha}^{-1}\right)$, is soil $\mathrm{C}$ calculated at steady state $\left(\mathrm{t} \mathrm{ha} \mathrm{h}^{-1}\right)$, and is plant $\mathrm{C}$ input used in the previous iteration $\left(\mathrm{t} \mathrm{ha}^{-1}\right)$.

The simulation of SOC at steady state also provides the starting proportions of SOC in the different active compartments of DPM, resistant plant material (RPM), microbial biomass (BIO) and HUM. Inert organic matter (IOM) is defined in RothC as the fraction of SOM that is biologically inert with a radioactive age more than 50,000 years. This was set using the equation given by Falloon et al. (1998). The proportions of SOC in the different pools characterise the decomposability of the SOM. This can then be used to run the model forward and determine how changes on organic matter inputs and weather conditions will affect the long term sequestration of $\mathrm{C}$ in the soil.

Following the approach given by Smith et al. (2005), it was assumed that plant inputs in the control, $\left(\mathrm{t} \mathrm{ha}{ }^{-1}\right)$, were equivalent to those calculated at steady state, and plant inputs in the fertilized trials, $\left(\mathrm{t} \mathrm{ha}^{-1}\right)$, could be obtained using the ratio of biological yield in the trial, ( $\left.\mathrm{t} \mathrm{ha}^{-1}\right)$, and the control, ( $\left.\mathrm{t} \mathrm{ha}^{-1}\right)$ : (4)However, this ratio did not provide a good fit to the chemical fertilizer trial measurements, overestimating plant inputs by a factor close to the harvest index. Therefore, plant inputs were instead calculated using the following formula to account for harvest index (HI):

The values for biological yield and harvest index are given in Table 2. The model was then run for each trial, starting with SOC pools calculated for the control and estimating plant and organic fertilizer inputs as described above.

Model evaluation: The accuracy of simulations of the measured values in the field trials was quantified as described by Smith et al. (1996). The correlation coefficient ( $r$ ) was used to determine degree of association between simulations and measurements. The percentage bias was calculated as the relative error. The root mean squared error ( $R M S E$ ) provided average percentage deviation of simulated soil $C$ from measured values; this value was used as an estimate of uncertainty in the simulation of the amount and decomposability of $\mathrm{C}$ added to the soil in the organic fertilizer. Ideally, in order to capture the long term SOM turnover processes, the accuracy of the simulations would be evaluated against measurements from long term trials where composted poultry manure and bioslurry had been added annually for at least 25 years. However, these long term trials do not yet exist. The evaluation presented here provides an assessment of how well the model captures the short term decomposability of the organic matter in the bioslurry and compost. Because these are derived from newly digested and decomposed fresh plant materials, it can be assumed that these materials are turning over rapidly. Therefore, the decomposability of the organic fertilizers can be defined using the relatively short term trials presented here. After several years of decomposition, the organic matter added to the soil can be treated as being a part of the $\mathrm{SOM}$, the longer term decomposability being determined by the proportions of $\mathrm{C}$ that have entered the different $\mathrm{SOC}$ pools defined in the model, as given by the short term decomposition processes. RothC simulations of long term SOC turnover have already been rigorously evaluated in a wide range of different environments (Coleman and Jenkinson, 1996). Taken together with the short term evaluations of decomposability presented here, this then allows RothC to be used with confidence to simulate the long term projections of $\mathrm{C}$ sequestration associated with applications of bioslurry or compost. 
Simulation of carbon sequestration: The model was run forward to simulate changes in SOC over the next 100 years from 2012 to 2112 . The climate data for future climate scenarios from 2014 to 2100 were obtained using the following procedure:

1. Future monthly temperature and precipitation for four SRES emissions scenarios for the grid cell containing the site were extracted from the ClimGen Emissions Scenario dataset (Osborn et al., 2016). These scenarios were economic growth with globalization (A1B), economic growth with regionalization (A2), environmental protection with globalization (B1) and environmental protection with regionalization (B2).

2. Historic monthly temperature and precipitation were obtained from average monthly values over the period 2001-2013 for the relevant grid cell, extracted from CRU TS version 3.22 observed gridded dataset (Harris et al., 2013). This time period was chosen to coincide with the time period of on-site climate observations.

3. Future monthly climate anomalies were calculated for 2014 to 2100, for each SRES scenario by subtracting the CRU historic monthly average from the ClimGen future monthly climate.

4. Absolute future monthly temperature and precipitation for each SRES scenario were then calculated by applying monthly anomalies to average monthly climate for the site, calculated from on-site measurements covering the period 2001-2013.

5. Monthly potential evapotranspiration for 20012100 was calculated using the Thornthwaite method (1948)

6. We used this climate anomalies approach rather than using the ClimGenEmission Scenario forecasts directly because there were some small differences between the CRU observed data for the grid cell and the on-site measurements. These differences would have introduced a small additional error in the future climate. We used CRU observed data as the baseline for calculation of anomalies because CRU observed data were also used as the baseline for the ClimGen climate scenario generator (Osborn, 2009). This enables the calculated anomalies to be free from artefacts that can result from using data generated using different gridding methods.

\section{RESULTS}

Measured short term changes in soil carbon: The $\mathrm{N}$ treatments significantly $(p \leq 0.05)$ affected all parameters under study during both years (Table 3 ). In treatment $\mathrm{N}_{1}$, where no $\mathrm{N}$ was applied, after maize harvest 2013 , the soil C had increased by $0.4 \mathrm{t} \mathrm{ha}^{-1}$ to $12.7 \mathrm{t} \mathrm{ha}^{-1}$. The maximum increase in soil C of $1.5 \mathrm{t} \mathrm{ha}^{-1}$ was observed in treatment $\mathrm{N}_{4}$ $(100 \% \mathrm{~N}$ applied as bioslurry) with a mean soil $\mathrm{C}$ content of $13.8 \mathrm{tha}^{-1}$.

Table 3. Effect of bioslurry, poultry manure and tillage systems on soil carbon stocks at $0-30 \mathrm{~cm}$ depth at maize harvest 2013.

\begin{tabular}{lcc}
\hline & \multicolumn{2}{c}{ SOC stocks $\left(\mathbf{t ~ h a}^{-1}\right)$} \\
\cline { 2 - 3 } & Year 2012 & Year 2013 \\
\hline Tillage Systems & & \\
MT & $13.10^{\mathrm{a}}$ & $13.61^{\mathrm{a}}$ \\
$\mathrm{CT}$ & $12.87^{\mathrm{b}}$ & $13.40^{\mathrm{b}}$ \\
DT & $12.61^{\mathrm{c}}$ & $13.05^{\mathrm{c}}$ \\
HSD5\% & 0.175 & 0.153 \\
Nitrogen treatments & & \\
$\mathrm{N}_{1}$ & $12.29^{\mathrm{d}}$ & $12.69^{\mathrm{e}}$ \\
$\mathrm{N}_{2}$ & $12.36^{\mathrm{d}}$ & $12.82^{\mathrm{e}}$ \\
$\mathrm{N}_{3}$ & $13.41^{\mathrm{ab}}$ & $13.69^{\mathrm{ab}}$ \\
$\mathrm{N}_{4}$ & $13.52^{\mathrm{a}}$ & $13.82^{\mathrm{a}}$ \\
$\mathrm{N}_{5}$ & $12.54^{\mathrm{d}}$ & $13.29^{\mathrm{cd}}$ \\
$\mathrm{N}_{6}$ & $12.45^{\mathrm{d}}$ & $13.34^{\mathrm{c}}$ \\
$\mathrm{N}_{7}$ & $12.72^{\mathrm{c}}$ & $13.11^{\mathrm{d}}$ \\
$\mathrm{N}_{8}$ & $12.75^{\mathrm{c}}$ & $13.58^{\mathrm{b}}$ \\
$\mathrm{N}_{9}$ & $13.34^{\mathrm{ab}}$ & $13.61^{\mathrm{ab}}$ \\
$\mathrm{N}_{10}$ & $13.25^{\mathrm{b}}$ & $13.57^{\mathrm{b}}$ \\
HSD 5\% & 0.246 & 0.226 \\
\hline
\end{tabular}

Note: Means in a column not sharing the same letters differ significantly from each other at $\mathrm{p} \leq 0.05(\mathrm{n}=4)$ according to Tukey's HSD; MT = minimum tillage; $\mathrm{CT}=$ conventional tillage; $\mathrm{DT}=$ deep tillage; Nitrogen treatments $\mathrm{N}_{1}-\mathrm{N}_{10}$ described in Table 1 .

The interaction between tillage systems and $\mathrm{N}$ treatments was also significant at $p \leq 0.05$ (Table 4). In treatment $\mathrm{N}_{1}$ (no N applied) with minimum tillage, at the 2013 harvest, mean soil $\mathrm{C}$ content had increased by $13 \%$ to $14.2 \mathrm{t} \mathrm{ha}^{-1}$ from $12.6 \mathrm{t} \mathrm{ha}^{-1}$. Maximum increase in SOC was observed in the minimum tillage systems; $1.6 \mathrm{t} \mathrm{ha}^{-1}$ in treatment $\mathrm{N}_{4}$ ( $100 \%$ bioslurry), followed by $1.4 \mathrm{t} \mathrm{ha}^{-1}$ with $\mathrm{N}_{9}(25 \%$ chemical fertilizer, $50 \%$ poultry manure and $25 \%$ bioslurry), and $1.3 \mathrm{t} \mathrm{ha}^{-1}$ with $\mathrm{N}_{3}(100 \%$ poultry manure) treatment. A small decrease in SOC was observed in the deep tillage system with treatment $\mathrm{N}_{1}$ where no $\mathrm{N}$ was applied.

Simulated short term changes in soil carbon: Plots of simulated and measured SOC contents are given in Figure 1. Simulated results of treatments $\mathrm{N}_{1}$ (control), $\mathrm{N}_{3}(100 \%$ poultry manure) and $\mathrm{N}_{5}(50 \%$ poultry manure) provide a good fit to experimental data, with simulated values within the $95 \%$ confidence interval of measurements. The simulated results of treatment $\mathrm{N}_{4} \quad(100 \%$ bioslurry $)$ significantly deviated from experimental measurements, suggesting the bioslurry used was less degraded than in 
experiments used to obtain the DPM:HUM ratio for bioslurry by Smith et al. (2014).

Table 4. Effect of interaction of tillage systems and nitrogen treatments on soil carbon stocks at 0-30 cm depth at maize harvest 2013.

\begin{tabular}{|c|c|c|}
\hline \multirow[t]{2}{*}{ 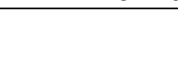 } & \multicolumn{2}{|c|}{ SOC Stocks $\left(\mathrm{t} \mathrm{ha}^{-1}\right)$} \\
\hline & Year 2012 & Year 2013 \\
\hline$\overline{\mathrm{MT}} \times \mathrm{N}_{1}$ & $12.50^{\mathrm{j}-\mathrm{n}}$ & $12.63^{\mathrm{n}}$ \\
\hline $\mathrm{MT} \times \mathrm{N}_{2}$ & $12.56^{\mathrm{i}-\mathrm{m}}$ & $12.96^{\mathrm{k}-\mathrm{n}}$ \\
\hline $\mathrm{MT} \times \mathrm{N}_{3}$ & $13.76^{\mathrm{ab}}$ & $13.97^{\mathrm{a}-\mathrm{c}}$ \\
\hline $\mathrm{MT} \times \mathrm{N}_{4}$ & $13.81^{\mathrm{a}}$ & $14.22^{\mathrm{a}}$ \\
\hline $\mathrm{MT} \times \mathrm{N}_{5}$ & $12.79^{\mathrm{g}-\mathrm{k}}$ & $13.56^{\mathrm{c}-\mathrm{h}}$ \\
\hline $\mathrm{MT} \times \mathrm{N}_{6}$ & $12.62^{\mathrm{h}-\mathrm{m}}$ & $13.58^{\mathrm{b}-\mathrm{g}}$ \\
\hline $\mathrm{MT} \times \mathrm{N}_{7}$ & $13.07^{\mathrm{d}-\mathrm{h}}$ & $13.50^{\mathrm{d}-\mathrm{i}}$ \\
\hline $\mathrm{MT} \times \mathrm{N}_{8}$ & $12.85^{\mathrm{f}-\mathrm{j}}$ & $13.78^{\mathrm{b}-\mathrm{e}}$ \\
\hline $\mathrm{MT} \times \mathrm{N}_{9}$ & $13.57^{\mathrm{a}-\mathrm{c}}$ & $13.98^{\mathrm{ab}}$ \\
\hline $\mathrm{MT} \times \mathrm{N}_{10}$ & $13.48^{\mathrm{a}-\mathrm{d}}$ & $13.93^{\mathrm{a}-\mathrm{c}}$ \\
\hline $\mathrm{CT} \times \mathrm{N}_{1}$ & $12.31^{1-\mathrm{n}}$ & $12.87^{1-\mathrm{n}}$ \\
\hline $\mathrm{CT} \times \mathrm{N}_{2}$ & $12.31^{1-n}$ & $12.86^{1-n}$ \\
\hline $\mathrm{CT} \times \mathrm{N}_{3}$ & $13.50^{\mathrm{a}-\mathrm{d}}$ & $12.76^{\mathrm{b}-\mathrm{f}}$ \\
\hline $\mathrm{CT} \times \mathrm{N}_{4}$ & $13.55^{\mathrm{a}-\mathrm{c}}$ & $13.82^{\mathrm{a}-\mathrm{d}}$ \\
\hline $\mathrm{CT} \times \mathrm{N}_{5}$ & $12.51^{\mathrm{i}-\mathrm{n}}$ & $13.35^{\mathrm{f}-\mathrm{k}}$ \\
\hline $\mathrm{CT} \times \mathrm{N}_{6}$ & $12.49^{\mathrm{j}-\mathrm{n}}$ & $13.39^{\mathrm{e}-\mathrm{j}}$ \\
\hline $\mathrm{CT} \times \mathrm{N}_{7}$ & $12.71^{\mathrm{h}-1}$ & $13.14^{\mathrm{i}-1}$ \\
\hline $\mathrm{CT} \times \mathrm{N}_{8}$ & $12.75^{\mathrm{g}-1}$ & $13.61^{\mathrm{b}-\mathrm{g}}$ \\
\hline $\mathrm{CT} \times \mathrm{N}_{9}$ & $13.27^{\mathrm{c}-\mathrm{f}}$ & $13.57^{\mathrm{b}-\mathrm{g}}$ \\
\hline $\mathrm{CT} \times \mathrm{N}_{10}$ & $13.32^{\mathrm{b}-\mathrm{e}}$ & $13.63^{\mathrm{b}-\mathrm{g}}$ \\
\hline $\mathrm{DT} \times \mathrm{N}_{1}$ & $12.07^{\mathrm{n}}$ & $12.59^{\mathrm{n}}$ \\
\hline $\mathrm{DT} \times \mathrm{N}_{2}$ & $12.22^{\mathrm{mn}}$ & $12.63^{n}$ \\
\hline $\mathrm{DT} \times \mathrm{N}_{3}$ & $12.97^{\mathrm{e}-\mathrm{i}}$ & $13.35^{\mathrm{f}-\mathrm{j}}$ \\
\hline $\mathrm{DT} \times \mathrm{N}_{4}$ & $13.18^{\mathrm{c}-\mathrm{g}}$ & $13.42^{\mathrm{k}-\mathrm{n}}$ \\
\hline $\mathrm{DT} \times \mathrm{N}_{5}$ & $12.30^{1-n}$ & $12.95^{\mathrm{j}-\mathrm{m}}$ \\
\hline $\mathrm{DT} \times \mathrm{N}_{6}$ & $12.22^{\mathrm{mn}}$ & $13.05^{\mathrm{j}-\mathrm{m}}$ \\
\hline $\mathrm{DT} \times \mathrm{N}_{7}$ & $12.38 \mathrm{k}^{1-\mathrm{n}}$ & $12.69^{\mathrm{mn}}$ \\
\hline $\mathrm{DT} \times \mathrm{N}_{8}$ & $12.65^{\mathrm{h}-\mathrm{m}}$ & $13.34^{\mathrm{g}-\mathrm{k}}$ \\
\hline $\mathrm{DT} \times \mathrm{N}_{9}$ & $13.18^{\mathrm{c}-\mathrm{g}}$ & $13.29^{\mathrm{g}-\mathrm{k}}$ \\
\hline $\mathrm{DT} \times \mathrm{N}_{10}$ & $12.94^{\mathrm{e}-\mathrm{j}}$ & $13.16^{\mathrm{h}-1}$ \\
\hline HSD $5 \%$ & 0.451 & 0.412 \\
\hline
\end{tabular}

Note: Means in a column not sharing the same letters differ significantly from each other at $\mathrm{p} \leq 0.05(\mathrm{n}=4)$ according to Tukey's HSD.

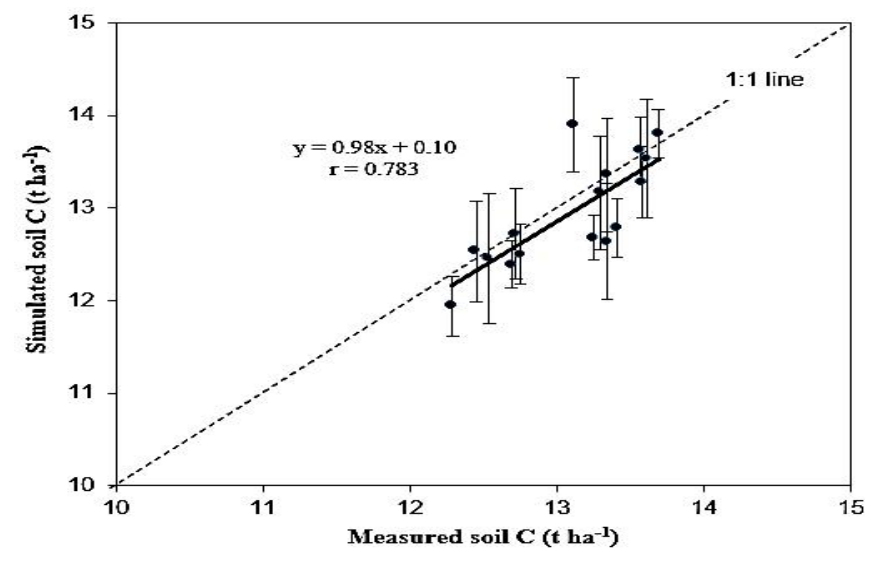

Figure 1. Comparison of simulated and measured soil $C$ in trials that have not been used in model development.

In order to provide a fit to experimental data, a DPM:HUM ratio closer to 10 is needed. This ratio was used for the remaining trials without further adjustment, allowing evaluation of simulations against independent data. The simulations for $\mathrm{N}_{6}\left(50 \%\right.$ bioslurry), $\mathrm{N}_{8}(25 \%$ poultry manure and $25 \%$ bioslurry), $\mathrm{N}_{9}(50 \%$ poultry manure and $25 \%$ bioslurry) and $\mathrm{N}_{10}$ (25\% poultry manure and $50 \%$ bioslurry) provide a good fit to experimental data without further adjustment, while treatment $\mathrm{N}_{7}(50 \%$ poultry manure and $50 \%$ bioslurry) provides reasonable fit but with one point lying just outside the $95 \%$ confidence interval. The value of RMSE for these independent trials $\left(\mathrm{N}_{3}\right.$ and $\left.\mathrm{N}_{5}-\mathrm{N}_{10}\right)$ was $2.87 \%$, which is less than the value of RMSE at the $95 \%$ confidence interval of the experimental data $(3.80 \%)$, so confirming that the simulations provide a good fit to experimental data. These simulations also showed a positive correlation to measured SOC (Fig. 1).An $F$-test indicated that this correlation is highly significant $(\mathrm{P}<0.05)$, suggesting strong association between simulated and measured values. The correspondence and association between simulated and measured values, suggests that the model can reliably be used to estimate the decomposition of these differently treated organic manures, simulating changes in soil C with an uncertainty of $2.87 \%$.

Simulation of long term carbon sequestration: Having determined the uncertainty using short term trials, the simulations were extended to estimate soil $\mathrm{C}$ sequestration over 100 years (Fig. 2). It should be noted that longer term processes may introduce additional uncertainty that could not be quantified in short term trials, but this cannot be quantified due to the absence of long term trials using bioslurry. After 100 years of the same treatment, SOC content is close to steady state in all trials. Maximum simulated $\mathrm{C}$ sequestration over 100 years $\left(24.9 \pm 0.7 \mathrm{t} \mathrm{ha}^{-1}\right)$ was observed in treatment $\mathrm{N}_{4}$ (100\% bioslurry), which is significantly higher than $20.8 \pm 0.6 \mathrm{t} \mathrm{ha}^{-1}$ in the next highest treatment $\mathrm{N}_{7}(50 \%$ poultry manure and $50 \%$ bioslurry). No $\mathrm{C}$ sequestration is observed in treatment $\mathrm{N}_{1}$ (control) which is assumed to be at steady state. Assuming no change in climate, $\mathrm{C}$ sequestration over 100 years with $100 \%$ bioslurry is $7.5 \pm 0.2 \mathrm{tha}^{-1}$ greater than with $100 \%$ poultry manure. If the same amount of bioslurry and poultry manure are applied $\left(8.4 \mathrm{t} \mathrm{ha}^{-1}\right)$, predicted $\mathrm{C}$ sequestration over 100 years is $4.5 \pm$ $0.2 \mathrm{t} \mathrm{ha}^{-1}$ more for bioslurry than for poultry manure.

Carbon losses predicted in treatment $\mathrm{N}_{1}$ under different climate change scenarios revealed that maximum $\mathrm{C}$ loss was observed in B2 $\left(1.6 \pm 0.05 \mathrm{t} \mathrm{ha}^{-1}\right)$ and B1 $\left(1.6 \pm 0.05 \mathrm{tha}^{-1}\right)$, followed by A1B $\left(1.5 \pm 0.04 \mathrm{tha}^{-1}\right)$ and A2 $\left(1.4 \pm 0.04 \mathrm{tha}^{-1}\right)$ as compared to average present weather data. Carbon loss was not significantly correlated with temperature $\left(\mathrm{R}^{2}<0.01\right.$ 
for all scenarios), but was more highly correlated with soil water $\left(\mathrm{R}^{2}>0.6\right.$ for all scenarios). The average soil water content increased in order A2 $(49.1 \mathrm{~mm})<$ A1B $(49.5 \mathrm{~mm})$ $<\mathrm{B} 2(50.5 \mathrm{~mm})<\mathrm{B} 1(51.3 \mathrm{~mm})$, and $\mathrm{C}$ losses increased in a similar order $(\mathrm{A} 2<\mathrm{A} 1 \mathrm{~B}<\mathrm{B} 1=\mathrm{B} 2)$. Above an average soil water content of $50.5 \mathrm{~mm}$, soil water does not limit decomposition, so $\mathrm{C}$ losses for scenarios $\mathrm{B} 1$ and $\mathrm{B} 2$ are equivalent.

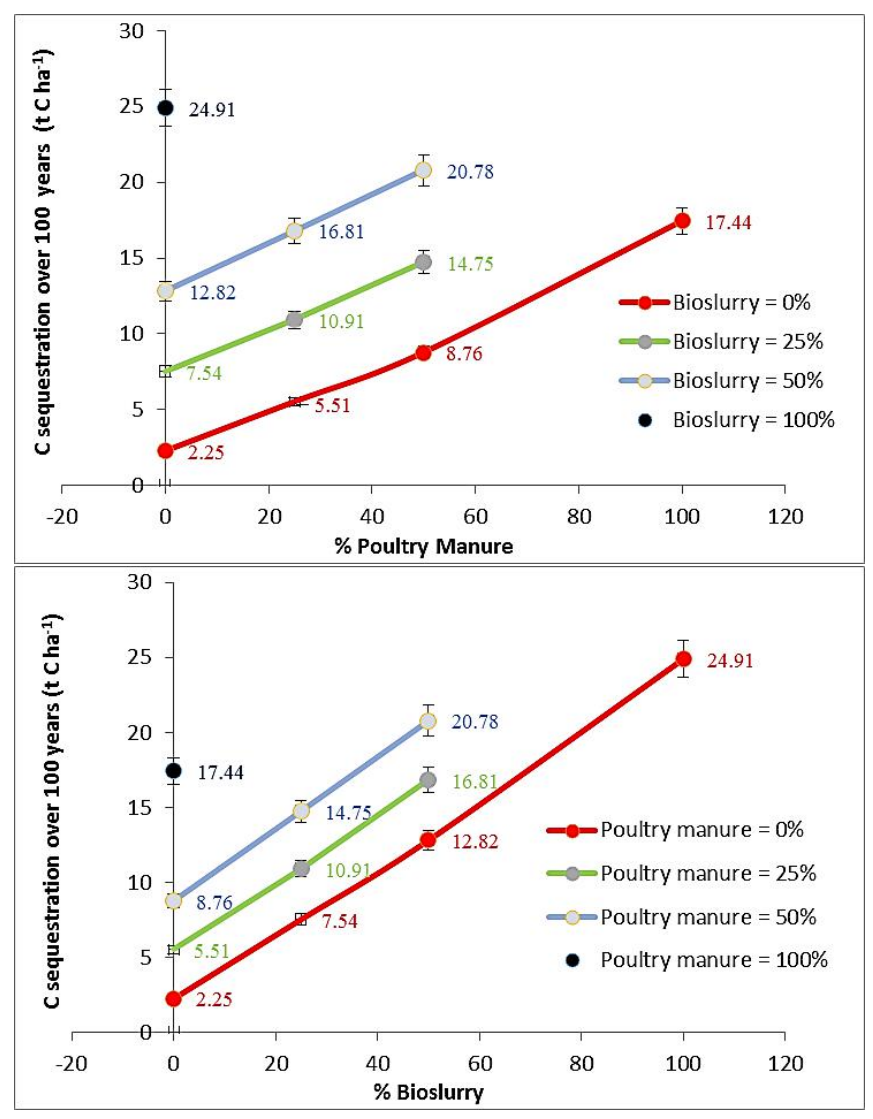

Figure 2. Carbon sequestration simulated over 100 years assuming annual application of the recommended rate of nitrogen $\left(135 \mathrm{~kg} \mathrm{ha}^{-1} \mathrm{~N}\right)$ in different combinations of fertilizer, bioslurry and poultry manure.

Simulations of change under different climatic scenarios (A1B, A2, B1, B2) between 2012 and 2112 are presented in Figure 3. Maximum $\mathrm{C}$ sequestration was observed in treatment $\mathrm{N}_{4}$ (100\% bioslurry) using present day weather data expressed as weather data averaged over the last 10 years $\left(23.5 \pm 0.7 \mathrm{tha}^{-1}\right)$, followed by statistically equivalent A2 $\left(21.3 \pm 0.6 \mathrm{t} \mathrm{ha}^{-1}\right), \mathrm{B} 1\left(20.6 \pm 0.6 \mathrm{t} \mathrm{ha}^{-1}\right), \mathrm{B} 2(20.6 \pm 0.6 \mathrm{t}$ $\left.\mathrm{ha}^{-1}\right)$ and A1B $\left(20.1 \pm 0.6 \mathrm{tha}^{-1}\right)$. A significant amount of C was sequestered by incorporating either poultry manure or bioslurry. More $\mathrm{C}$ is sequestered by incorporating bioslurry than poultry manure. The $\mathrm{C}$ stocks in treatment $\mathrm{N}_{2}(100 \%$ chemical fertilizer) were decreased by $0.2 \mathrm{t} \mathrm{ha}^{-1}$ under A1B and $\mathrm{N}_{1}$ (control) (Fig. 3). Climate change does not appear to negate the impact of organic fertilizers on $\mathrm{C}$ sequestration (Fig. 3).

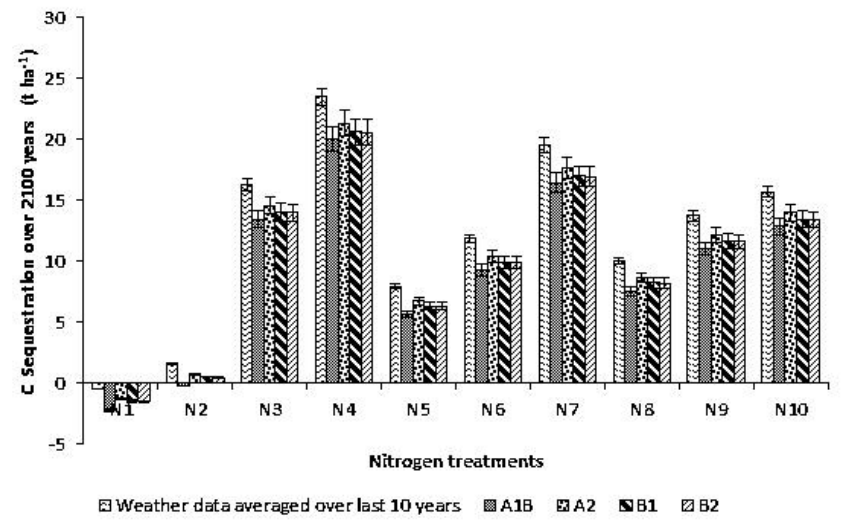

Figure 3. Simulated soil carbon sequestration under different future climatic scenarios between 2012 and 2100 for the different treatments in the trial. Note, error bars show the uncertainty in the simulations, which was calculated by comparison between simulations and experimental measurements to be $2.87 \%$.

\section{DISCUSSION}

Short term increases in SOC stocks were observed to be significantly greater with application of bioslurry than in the control where no $\mathrm{N}$ was applied, but no significant difference in soil $\mathrm{C}$ changes was observed with other treatments. This was in part due to inherent variability of the soils and organic fertilizers. Many authors have reported significant increases in SOC with application of organic fertilizers; Franzluebbers (2005) reported a significant increase in SOC with poultry manures, and Christensen (1996) observed significant increase in SOC with organic manure compared to chemical fertilizer; so a significant difference in treatments would be expected with higher rate of organic fertilizer application.

Minimum tillage significantly increased SOC stocks compared to conventional and deep tillage. This is likely to be due to increased microbial respiration in deep tilled soils, and is in agreement with the studies presented by Xiao-Bin et al. (2006), although in contrast to the findings of Powlson et al. (2014) and Blanco-Canqui and Lal (2008), who suggest that minimum tillage sequesters very little SOC. A strong interaction was observed between the impact on SOC stocks of tillage and organic fertilizer applications, suggesting minimum tillage results in more effective $\mathrm{C}$ sequestration from organic fertilizers than conventional or deep tillage. 
Accurate simulations of changes in SOC in poultry manure trials were obtained using parameters derived from earlier work (Smith et al., 2014). However, simulations of changes in SOC with bioslurry were not accurate. An increased DPM:HUM ratio was needed to provide simulations within experimental error of measurements, suggesting that bioslurry is less well digested than in earlier work by Schievano et al. (2011). This is supported by the relatively low rate of biogas production $\left(9 \mathrm{~kg} \mathrm{~d}^{-1} \mathrm{CH}_{4}\right.$ from $200 \mathrm{~kg} \mathrm{~d}^{-1}$ cattle manure). The reduced digestion of bioslurry can be attributed to the low retention time, which was only 30 days compared to the ideal 40 days required for complete digestion (Price and Cheremisinoff, 1981). A more complete digestion would result in more stabilized bioslurry, which would sequester more $\mathrm{C}$ at the same rate of application. However, more $\mathrm{C}$ would be lost during digestion, so less bioslurry would be produced for application to the soil. Further work is needed to optimize $\mathrm{C}$ sequestration from bioslurries produced at different retention times and different moisture contents.

Long term simulations suggest that $\mathrm{C}$ sequestration with continued bioslurry application will be significantly higher than for poultry manure. Bioslurry applications at the recommended $\mathrm{N}$ rate sequester $4.5 \pm 0.2 \mathrm{t} \mathrm{ha}^{-1}$ more soil $\mathrm{C}$ than the same amount of poultry manure. Losses in soil $\mathrm{C}$ associated with climate change are likely to be more than compensated for by application of organic fertilizers. The composted poultry manure actually contains more $\mathrm{C}$ than the bioslurry ( $354 \mathrm{~g} \mathrm{~kg}^{-1}$ compared to $336 \mathrm{~g} \mathrm{~kg}^{-1}$ ), but the $\mathrm{C}$ in the bioslurry has been more stabilized by the digestion process than the $\mathrm{C}$ in the poultry manure. This results in slower decomposition rate and a greater potential to sequester $\mathrm{C}$ in the soil following application of the bioslurry than the compost. An economic analysis of the proposed applications of organic fertilizers is given by Shahzad et al. (2015).

Conclusions: The application of organic manures to these soils in Pakistan increases soil $\mathrm{C}$ sequestration. Simulations suggest that addition of bioslurry at a rate of $8.4 \mathrm{tha}^{-1} \mathrm{y}^{-1}$ has potential to increase SOC over 100 years by $24.9 \pm 0.7 \mathrm{t} \mathrm{ha}^{-1}$, compared to other treatments, and can sequester $7.5 \pm 0.2 \mathrm{t}$ $\mathrm{ha}^{-1}$ more $\mathrm{C}$ than application of poultry manure at a rate of $7.5 \mathrm{t} \mathrm{ha}^{-1} \mathrm{y}^{-1}$. In this experiment, minimum tillage also retains more $\mathrm{C}$ in the soil than conventional or deep tillage. The sole application of chemical fertilizer decreased soil $\mathrm{C}$ stocks under A1B future climatic scenario. It is recommended that addition of bioslurry or poultry manure compost with minimum tillage would be an improved management practice to increase soil $\mathrm{C}$ sequestration, improve soil properties and to achieve maximum yield on a sustainable basis.
Acknowledgements: Funds provided by Higher Education Commission (HEC) of Pakistan for carrying out this Ph.D. research work under "Indigenous 5000 Fellowship Program" and "International Research Support Initiative Program" are highly acknowledged.

\section{REFERENCES}

Bashir, K., S. Ali, S. S. Ijaz and I. Ahmad. 2016. Effect of organic amendments on distribution, stability and carbon concentration of soil aggregates. Pak. J. Agri. Sci. 53:955-961.

Batlle-Bayer, L., N.H. Batjes and P.S. Bindraban. 2010. Changes in organic carbon stocks upon land use conversion in the Brazilian Cerrado: a review. Agric. Ecosyst. Environ. 137:47-58.

Bernal, M.P., M.A. Sanchez-Monedero, C. Paredes and A. Roig. 1998. Carbon mineralization from organic wastes at different composting stages during their incubation with soil. Agric. Ecosyst. Environ. 69:175-189.

Blanco-Canqui, H. and R. Lal. 2008. No-tillage and soilprofile carbon sequestration: An on-farm assessment. Soil Sci. Soc. Am. J. 72: 693-701.

Brake, J.D. 1992. A practical guide for composting poultry litter. MAFES Bulletin 981, June, 1992.Department of Poultry Science, Mississippi State University, USA. Available online at http://www.msstate.edu/dept/poultry/complit.htm

Bremner, J.M. and C.S. Mulvaney. 1982. Total nitrogen. In: A.L. Page, R.H. Miller and D.R. Keeny (eds.), Methods of Soil Analysis. American Society of Agronomy and Soil Science Society of America, Madison, pp.11191123.

Christensen, B.T. 1996. The Askov long-term experiments on animal manure and mineral fertilizers. In: D.S. Powlson, P. Smith and J.U. Smith (eds.), Evaluation of soil organic matter: models using existing datasets. NATO, ASI 138. Springer, Heidelberg, Germany, pp.301-312.

Coleman, K. and D.S. Jenkinson. 1996. RothC-26.3 - a model for the turnover of carbon in soil. In: D.S. Powlson, P. Smith and J.U. Smith (eds.), Evaluation of soil organic matter models using existing long-term datasets, NATO ASI Evaluation of soil organic matter: models using existing datasets. Springer, Heidelberg, Germany, pp.237-246.

Davidson, E.A. and I.L. Ackerman. 1993. Changes in soil carbon inventories following cultivation of previously untilled soils. Biogeochem. 20:161-193.

Ellert, B.H. and J.R. Bettany. 1998. Calculation of organic matter and nutrients stored in soils under contrasting management regimes. Can. J. Soil. Sci. 75:529-538.

Falloon, P., P. Smith, K. Coleman and S. Marshall. 1998. Estimating the size of the inert organic matter pool from 
total soil organic carbon content for use in the Rothamsted carbon model. Soil Biol. Biochem. 30:1207-1211.

Franzluebbers, A.J. 2005. Soil organic carbon sequestration and agricultural greenhouse gas emissions in the southeastern USA. Soil Till. Res. 83:120-147.

Harris, I., P.D. Jones, T.J. Osborn and D.H. Lister. 2013. Updated high-resolution grids of monthly climatic observations - the CRU TS 3.10 Dataset. Int. J. Climatol. 34:623-642.

Islam, S. 2006. Use of bio-slurry as organic fertilizer in Bangladesh agriculture. Proc. International workshop on the use bio-slurry for domestic biogas programs 27-28 September, Bangkok, Thailand.

Khalid, R., T. Mahmood, R. Bibi, M.T. Siddique, S. Alvi and S.Y. Naz. 2012. Distribution and indexation of plant available nutrients of rainfed calcareous soils of Pakistan. Soil Environ. 31:146-151.

Khan, A.U.H. and R. Lal. 2007. Potential for carbon sequestration in the soils of Afghanistan and Pakistan. In: R. Lal, M. Suleimenov, B.A. Stewart, D.O. Hansen and P. Doraiswamy (eds.), Climate change and terrestrial carbon sequestration in central Asia. Taylor \& Francis/Balkema, The Netherland, pp.235-249.

Khan, M.M., M.A. Khan, M. Abbas, M.J. Jaskani and M.A. Ali. 2006. Evaluation of potting media for the production of rough lemon nursery stock. Pak. J. Bot. 38:623-629.

Kingery, W.L., C.W. Wood, D.P. Delaney, J.C. Williams and G.I. Mullins. 1994. Impact of long-term land application of broiler litter on environmentally related soil properties. J. Environ. Qual. 23:139-147.

Knudsen, D., G.A. Peterson and P.F. Pratt. 1982. Lithium, sodium and potassium. In: R.H. Miller and D.R. Keeney (eds.), Methods of Soil Analysis, Vol. 2. American Society of Agronomy and Soil Science Society of America Journal, Madison, pp.225-246.

Lal, R. 2002. Soil carbon dynamics in cropland and range land. Environ. Pollut. 116:353-362.

Li, J.T. and B. Zhang. 2007. Paddy soil stability and mechanical properties as affected by long-term application of chemical fertilizer and animal manure in subtropical China. Pedosphere 17:568-579.

López-Bellido, R.J., J.M. Fontán, F.J. López-Bellido and L. López- Bellido. 2010. Carbon sequestration by tillage, rotation, and nitrogen fertilization in a Mediterranean Vertisol. Agron. J. 102:310-318.

Mellek, J.E., J. Dieckow, V.L. Silva, N. Faveretto, V. Pauletti, F.M. Vezzani and J.L.M. Souza. 2010. Dairy liquid manure and no-tillage: Physical and hydraulic properties and carbon stocks in a Cambisol of Southern Brazil. Soil Till. Res. 110:69-76.

Marcato, C.-E., R. Mohtar, J.C. Revel, P. Pouech, M. Hafidi and M. Guiresse. 2009. Impact of anaerobic digestion on organic matter quality in pig slurry. Int. Biodeter. Biodegr. 63:260-266.

Osborn, T.J. 2009. A user guide for ClimGen: a flexible tool for generating monthly climate data sets and scenarios. Available online at http://www.cru.uea.ac.uk/ timo/climgen/ClimGen_v102_userguide_2feb2009.pdf

Osborn, T.J., C.J. Wallace, I.C. Harris and T.M. Melvin. 2016. Pattern scaling using ClimGen: monthlyresolution future climate scenarios including changes in the variability of precipitation. Climatic Change 134:353-369.

Post, W.M. and K.C. Kwon. 2000. Soil carbon sequestration and land-use change: processes and potential. Glob. Change Biol. 6:317-327.

Powlson, D.S., C.M. Stirling, M.L. Jat, B.G. Gerard, C.A. Palm, P.A. Sanchez and K.G. Cassman. 2014. Limited potential of no-till agriculture for climate change mitigation. Nature Clim. Change 4:678-683.

Price, E.C. and P.N. Cheremisinoff. 1981. Biogas production and utilization. Energy Technology Series. Ann Arbor Science Publishers, Belford, Northumberland, UK. p. 146.

Ryan, J., G. Estefan and A. Rashid. 2001. Soil and Plant Analysis Lab Manual, 2 ${ }^{\text {nd }} \mathrm{Ed}$. International Centre for Agricultural Research in Dry Areas, Aleppo, Syria.

Shamsi, I.H., G. Jilani, G.P. Zhang and W. Kang. 2008. Cadmium stress tolerance through potassium nutrition in soybean. Asian J. Chem. 20:1099-1108.

Schievano, A., G. D'Imporzano, S. Salati and F. Adani. 2011. On-field study of anaerobic digestion full-scale plants (Part I): An on-field methodology to determine mass, carbon and nutrients balance. Bioresour. Technol. 102:7737-7744.

Shahzad, K., A. Khan, J.U. Smith, M. Saeed and A.A. Khan. 2015. Response of maize to different nitrogen sources and tillage systems under humid subtropical conditions. J. Anim. Plant Sci. 25:189-197.

Smith, G.R. 2000. Towards an efficient method for measuring soil organic carbon stocks in forests. In: R. Lal, J.M. Kimble, R.F. Follett and B.A. Stewart (eds.) Assessment Methods for Soil Carbon. Lewis Publishers, CRC Press LLC, USA, pp.293-310.

Smith, J.U., P. Smith and T.M. Addiscott. 1996. Quantitative methods to evaluate and compare soil organic matter (SOM) models. In: D.S. Powlson, P. Smith and J.U. Smith (eds.), Evaluation of soil organic matter models using existing long-term datasets, NATO ASI Evaluation of soil organic matter: models using existing datasets. Springer, Heidelberg, Germany, pp.181-200.

Smith, J., A. Abegaz, R. Matthews, M. Subedi, R. Orskov, V. Tumwesige and P. Smith. 2014. What is the potential for biogas digesters to improve soil carbon sequestration in Sub-Saharan Africa? Biomass Bioenerg. 70:73-86. 
Smith, P., M. Wattenbach, S. Zaehle, R. Hiederer and R.J.A. Jones, L. Montanarella, M.D.A. Rounsevell, I. Reginster and F. Ewert. 2005. Projected changes in mineral soil carbon of European croplands and grasslands, 19902080. Glob. Change Biol. 11:2141-2152.

Smith, P., D. Martino, Z. Cai, D. Gwary, H. Janzen, P. Kumar, B. McCarl, S. Ogle, F. O'Mara, C. Rice, B. Scholes, O. Sirotenko, M. Howden, T. McAllister, G. Pan, V. Romanenkov, U. Schneider, S. Towprayoon, M. Wattenbach and J. Smith. 2008. Greenhouse gas mitigation in agriculture. Philos. T. Roy. Soc. B. 363:789-813.

Steel, R.G.D. and J.H. Torrie. 1984. Principles and Procedures of Statistics, $2^{\text {nd }}$ Ed. McGraw Hill Book Co. Inc. Singapore. pp.172-178.

Thornthwaite, C.W. 1948. An approach toward a rational classification of climate. Geogr. Review 38:55-94.

Van Schouwenberg, J.C.H. and I. Walinge. 1973. Methods of Analysis for Plant Material. Agric. Univ., Wageningen, The Netherlands.

Victoria, R., S. Banwart, H. Black, J. Ingram, H. Joosten, E. Milne, E. Noellemeyer and Y. Baskin. 2012. The benefits of soil carbon: Managing soils for multiple economics, social and environmentak benefits. UNEP Year Book 2012; pp.19-33. Available online at http://www.unep.org/yearbook/2012/pdfs/UYB_2012_C H_2.pdf

Walkley, A. and I.A. Black. 1934. An examination of the Degtjareff method for determining soil organic matter, and a proposed modification of the chromic acid titration method. Soil Sci. 37:29-38.

Watanabe, F.S. and S.R. Olsen.1965. Test of an ascorbic acid method for determining phosphorus in water and $\mathrm{NaHCO}_{3}$ extracts from soil. Soil Sci. Soc. Am. Proc. 29:677-678.

Winkleman, G.E., R. Amine, W.A. Rice and M.B. Tahir. 1986. Potassium in plant. In: Methods Manual Soils Laboratory. Barani Agric. Res. and Dev. Project. National Agricultural Research Centre, Islamabad, Pakistan; pp.39-40.

Xiao-Bin, W., C.D. Xiong, W.B. Hoogmoed, O. Oenema and U.D. Perdok. 2006. Potential effect of conservation tillage on sustainable land use: a review of global longterm studies. Pedosphere 16:587-595. 